\title{
Evaluation of bituminous sub-ballast manufactured at low temperatures as an alternative for the construction of more sustainable railway structures
}

\author{
L. Pirozzolo, M. Sol-Sánchez, F. Moreno-Navarro, G. Martínez-Montes, M. C. Rubio-Gámez凹 \\ Laboratory of Construction Engineering (LabIC.UGR), Department of Construction Engineering (ICPI), School of Civil \\ Engineering (ETSICCP), University of Granada, (Granada, Spain) \\ \mcrubio@ugr.es
}

Received 15 April 2016 Accepted 10 November 2016 Available on line 26 July 2017

\begin{abstract}
Hot bituminous mixtures are becoming widely used in modern railway tracks in the sub-ballast layer. The reason is that these materials allow for both an increase in bearing capacity and greater protection of the substructure respect the traditional granular sub-ballast. Despite these advantages, the fact that these materials are manufactured at a temperature of $160^{\circ} \mathrm{C}$ means that their application can lead to an important increase in construction costs, pollution and energy consumption. This paper aims to study the possibility of using WMA manufactured at lower temperatures, as bituminous sub-ballast, in order to save energy and reduce emissions throughout the production process, as well as diminish the global costs of this layer. To this end, this study focuses on a comparison of the mechanical behaviour of warm and hot bituminous mixtures as subballast under various loading conditions. The results indicate that WMA offers mechanical behaviour that is comparable to conventional HMA.
\end{abstract}

KEYWORDS: Limestone; Temperature; Deformation; Mechanical properties

Citation/Citar como: Pirozzolo, L.; Sol-Sánchez, M.; Moreno-Navarro, F.; Martínez-Montes, G.; Rubio-Gámez, M.C. (2017) Evaluation of bituminous sub-ballast manufactured at low temperatures as an alternative for the construction of more sustainable railway structures. Mater. Construcc. 67 [327], e128. http://dx.doi.org/10.3989/mc.2017.04816

RESUMEN: Evaluación del subbalasto bituminoso a partir de mezclas a baja temperatura, como alternativa para la construcción de infraestructuras ferroviarias más sostenibles. Las mezclas bituminosas en caliente en infraestructuras ferroviarias son una alternativa cada vez más extendida en vías de altas prestaciones, para mejorar la capacidad portante de la vía y el grado de protección del resto de la subestructura. Sin embargo, el sub-balasto bituminoso presenta una serie de limitaciones asociadas al posible incremento de costes de construcción y a problemas medioambientales derivados de la utilización de mezclas bituminosas en caliente fabricadas a $160^{\circ} \mathrm{C}$. Este trabajo, tiene como objetivo estudiar la posibilidad de utilizar WMA fabricado a temperaturas inferiores, como sub-balasto bituminoso con el fin de ahorrar energía, reducir las emisiones y disminuir los costes constructivos de esta capa. Así, este estudio se centra en la comparación entre el comportamiento mecánico de mezclas bituminosas semicalientes y calientes como sub-balasto, bajo diferentes condiciones de carga. Los resultados muestran que el sub-balasto semicaliente presenta una respuesta mecánica comparable a las soluciones convencionales.

PALABRAS CLAVE: Caliza; Temperatura; Deformación; Propiedades mecánicas.

ORCID ID: L. Pirozzolo (http://orcid.org/0000-0003-1722-4046); M. Sol-Sánchez (http://orcid.org/0000-0003-37567556); F. Moreno-Navarro (http://orcid.org/0000-0001-6758-8695); G. Martínez-Montes (http://orcid.org/0000-00030677-8318); M.C. Rubio-Gámez (http://orcid.org/0000-0002-1874-5129)

Copyright: (C) 2017 CSIC. This is an open-access article distributed under the terms of the Creative Commons Attribution License (CC BY) Spain 3.0. 


\section{INTRODUCTION}

The sub-ballast is the layer between the ballast and subgrade, and is generally composed of graded sand and gravel. This is employed in the majority of European high-speed lines with the aim of distributing and reducing the cyclic loads transmitted to the underlying subgrade layer to an acceptable level of stress, and among others, to protect the subgrade from climatic effects $(1,2)$. Thus, bearing capacity and impermeability are the principal functions of the sub-ballast layer that must be ensured to lengthen the service life of the infrastructure and reduce its maintenance costs. Nonetheless, use of this granular configuration may have some drawbacks. First of all, it requires an adequate thickness of the layer to ensure an optimal bearing capacity, which involves the consumption of significant natural aggregates, with high costs of transport from the quarry and negative environmental effects. Moreover, other research works have shown that the granular material tends to lose its filter and waterproofing properties, which has important consequences for the deformation of the tracks $(3,4)$.

In this context, the use of HMA to replace the granular sub-ballast is a solution that has the potential to ensure the required bearing capacity and impermeability, whilst simultaneously reducing the thickness of the layer to $12-15 \mathrm{~cm}$, compared with the $22-25 \mathrm{~cm}$ used in the conventional granular design. Furthermore, other studies have observed that the use of HMA as a sub-ballast allows for a reduction in vibration levels throughout the track, therefore reducing noise (5-7). From an economic point of view, the transportation distance plays an important role in determining the cost of the sub-ballast layer. It has been shown that the cost of granular sub-ballast is highly dependent on the local availability of quarries with materials that are suitable for meeting high-speed track standards, and the cost of these materials can double for distances to quarry varying from 20 to $80 \mathrm{~km}(8)$. For the bituminous layer, the cost of the bitumen is one of the key influential factors affecting the cost of the bituminous sub-ballast. When comparing the cost of both materials, it has been shown that the use of bituminous sub-ballast is more appropriate than granular material when transportation distances from the quarry are greater than $60-80 \mathrm{~km}$. Moreover, assuming a variation of $30 \%$ of bitumen content, it would suppose a variation on the bituminous sub-ballast cost of about $10 \%$ (3).

Furthermore, it has been demonstrated that the waterproof characteristics of the bituminous subballast layer allow for a reduction in the lateral slope of the track from $5 \%$ to almost 3\%. This factor can lead to a reduction of around $200 \mathrm{~m}^{3} / \mathrm{km} /$ track in the volume of ballast required for this solution. This saving in ballast material could be approximately equivalent to $5 \%$ of the price of the bituminous sub-ballast layer, considering the average costs of the ballast material suitable for highspeed lines $(3,8)$.

The type of mixture more commonly used within the track is a dense-graded bituminous mixture with a maximum aggregate size of $22-25 \mathrm{~mm}$ manufactured with characteristics that are suitable for the construction of road pavements (9). For its application as sub-ballast, however, some authors recommend increasing the content of bitumen by $0.5 \%$ in comparison with that considered as optimum for highway applications in mixtures with air-voids content of $1-3 \%(10)$.

From a sustainable point of view, the production of hot-mix asphalt (HMA) emits pollutant gases and consumes fuel or gas during the manufacturing process. These effects are primarily due to the drying and heating of mineral aggregates and bitumen at temperatures of approximately $160{ }^{\circ} \mathrm{C}$ or higher. With the implementation of the Kyoto Protocol (horizon 2020) the signatory countries are undertaking measures to reduce these atmospheric emissions. Thus, to achieve these goals, there is an important role for the use of new manufacturing technologies, and in particular those that are capable of consuming less energy than those used in the production of traditional HMA whilst maintaining the in-service mechanical performance of the material (11-16).

One such technology, recently developed, is known as warm mix asphalt (WMA). WMA is able to reduce the viscosity of the binder as well as the mixing and compaction temperatures by $20-30{ }^{\circ} \mathrm{C}$, through the use of organic additives, chemical additives, and water-based or water-containing foaming processes (13-16).

WMA technologies offer a number of benefits in comparison with HMA, particularly in terms of cost, environmental impact, and production and paving issues (16-19). The most important advantages can be summarized as a reduction of emissions; the improvement of working conditions by reducing the exposure to fuel emissions, fumes and heat; lower energy consumption; and the extension of the paving season $(13,14,16,19,20)$. Given these advantages, its use is becoming more popular in road construction, and it has great potential for application as bituminous sub-ballast in railway tracks.

Thus, the aim of the present paper is to compare the effects of using a WMA as sub-ballast with those of a conventional HMA, analysing its mechanical performance under the main failure modes that occur during the service life of this layer. In particular, the current study examines, among others, resistance to plastic and punching deformations due to ballast punching, bearing capacity, stress dissipation, and waterproofing properties, whilst taking into account both standard temperatures of service adverse climate conditions. 


\section{MATERIALS AND METHODS}

\subsection{Materials}

In this study, two type of bituminous mixtures were employed as sub-ballast layer: A hot mix asphalt (HMA) manufactured at $160^{\circ} \mathrm{C}$, and a warm mix asphalt (WMA) similar to traditional HMA in which a chemical additive has been used to reduce the manufacturing temperature to $25^{\circ} \mathrm{C}$. Both asphalt mixtures studied as sub-ballast were a dense-graded mix type AC 22 S (UNE-EN 131081:2007). Limestone aggregates were used for the different fractions $0 / 6,6 / 12,12 / 18$ and $18 / 25$, presenting appropriate properties for their use in asphalt mixes in accordance with Spanish PG-3 regulations. The characteristics of the aggregates are shown in Table 1.
The filler used was Portland cement, CEM II/B-L $32.5 \mathrm{~N}$ (UNE-EN 197-1:2011). 95\% of this filler has a particle size smaller than $0.063 \mathrm{~mm}$ with an apparent density (UNE-EN 1097-3:1999) of $0.7 \mathrm{Mg} / \mathrm{m}^{3}$. The same mineral skeleton (Figure 1) and bitumen type B 50/70 with a binder content of $4.25 \%$ and 54 $\mathrm{dmm}$ of penetration (UNE-EN 1426:2007), $54.4^{\circ} \mathrm{C}$ of softening point (UNE-EN 1427:2007), were used to manufacture the mixes.

The WMA was manufactured at $135^{\circ} \mathrm{C}$ and compacted at $125^{\circ} \mathrm{C}$, through the use of a surfactant chemical additive that reduces the surface tension of asphalt binder and improves the moisture resistance of pavements by serving as an antistrip (21). The additive was introduced at $0.5 \%$ by weight (additive density: $1.01 \mathrm{gm} / \mathrm{cc}$ ) and it had previously been mixed with the bitumen at a temperature of $160^{\circ} \mathrm{C}$ by using a conventional blender,

TABLE 1. Reference values of the aggregates

\begin{tabular}{|c|c|c|c|c|c|}
\hline & & $18 / 25$ & $12 / 18$ & $6 / 12$ & $0 / 6$ \\
\hline Test - aggregate & Sieves (mm) & $\begin{array}{c}\% \text { of } \\
\text { material } \\
\text { passing }\end{array}$ & $\begin{array}{c}\% \text { of } \\
\text { material } \\
\text { passing }\end{array}$ & $\begin{array}{c}\% \text { of } \\
\text { material } \\
\text { passing }\end{array}$ & $\begin{array}{c}\% \text { of } \\
\text { material } \\
\text { passing }\end{array}$ \\
\hline \multirow[t]{15}{*}{ Particle grain size (UNE-EN 933-1) } & 31.5 & 100 & 100 & 100 & 100 \\
\hline & 25 & 90 & 100 & 100 & 100 \\
\hline & 22.4 & 54 & 100 & 100 & 100 \\
\hline & 16 & 7 & 100 & 100 & 100 \\
\hline & 12.5 & 2 & 53 & 100 & 100 \\
\hline & 11.2 & 2 & 26 & 97 & 100 \\
\hline & 10 & 2 & 13 & 83 & 100 \\
\hline & 8 & 2 & 9 & 52 & 100 \\
\hline & 5.6 & 2 & 7 & 7 & 98 \\
\hline & 4 & 2 & 5 & 4 & 89 \\
\hline & 2 & 2 & 3 & 3 & 57 \\
\hline & 0.5 & 2 & 2 & 2 & 28 \\
\hline & 0.25 & 2 & 2 & 2 & 23 \\
\hline & 0.125 & 2 & 0 & 0 & 19 \\
\hline & 0.063 & 2.3 & 0.1 & 0.3 & 12.3 \\
\hline $\begin{array}{l}\text { Coarse aggregate shape. Flakiness } \\
\text { index (UNE-EN 933-3) }\end{array}$ & & 8 & 12 & 10 & - \\
\hline $\begin{array}{l}\text { Percentage of fractured face } \\
\text { (UNE-EN 933-5) }\end{array}$ & & 99 & 99 & 98 & - \\
\hline $\begin{array}{l}\text { Resistance to fragmentation } \\
\text { (Los Angeles coefficient) } \\
\text { (UNE-EN 1097-2) }(<25)\end{array}$ & & 23 & 23 & 23 & - \\
\hline $\begin{array}{l}\text { Cleaning (organic impurity content) } \\
\text { (UNE-EN 146130) }(<0,5 \%)\end{array}$ & & 0.2 & 0.4 & 0.4 & - \\
\hline $\begin{array}{l}\text { Sand equivalent (UNE-EN 933-8) } \\
(>50)\end{array}$ & & - & - & - & 77 \\
\hline \multirow{4}{*}{$\begin{array}{l}\text { Relative density and absorption } \\
\text { (UNE-EN 1097-6) }\end{array}$} & Apparent density $\left(\mathrm{Mg} / \mathrm{m}^{3}\right)$ & 2.86 & 2.85 & 2.86 & 3.01 \\
\hline & $\operatorname{ADSS}\left(\mathrm{Mg} / \mathrm{m}^{3}\right)$ & 2.83 & 2.81 & 2.81 & 2.96 \\
\hline & Density after drying $\left(\mathrm{Mg} / \mathrm{m}^{3}\right)$ & 2.84 & 2.83 & 2.83 & 2.97 \\
\hline & Water absorption after immersion (\%) & 0.39 & 0.49 & 0.62 & 0.56 \\
\hline
\end{tabular}




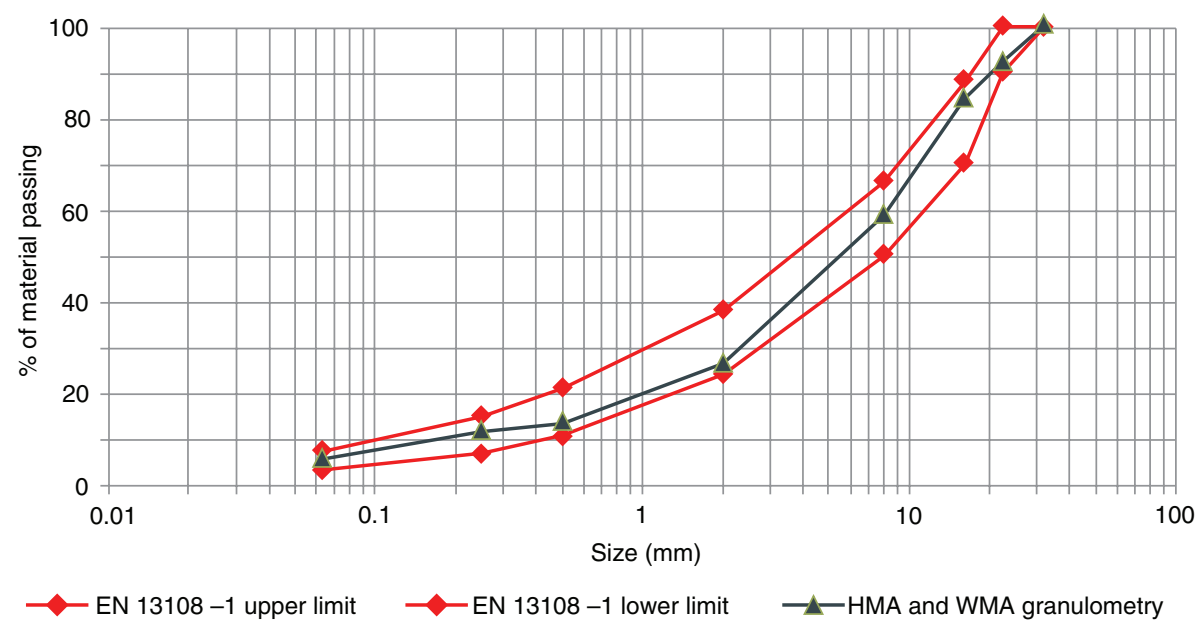

Figure 1. Mineral skeleton of both mixes.

TABLE 2. Testing plan

\begin{tabular}{|c|c|c|c|c|}
\hline Test & Standard & Temperature $\left({ }^{\circ} \mathrm{C}\right)$ & Property tested & Main parameters \\
\hline Marshall & NLT $159-00$ & 60 & $\begin{array}{l}\text { Physical and } \\
\text { mechanical properties }\end{array}$ & $\begin{array}{l}\text {-Bulk density } \\
\text {-Maximum density } \\
\text {-Air voids } \\
\text {-Marshall stability } \\
\text {-Marshall flow }\end{array}$ \\
\hline Water sensitivity & EN 12697-12:2009 & 15 & Water effect & -Retained indirect tensile strength \\
\hline Indirect tensile tests & EN 12697-26:2012 & 25 & -Stiffness & -Stiffness modulus \\
\hline Triaxial cyclic test & UNE-EN 12695:2006 & $25,40,60$ & -Plastic deformation & -Creep modulus \\
\hline Punching test & - & 25,40 & (settlement) & -Creep slope -Permanent strain \\
\hline Plate bearing test & UNE-EN 103807:2008 & 25,40 & $\begin{array}{l}\text {-Bearing capacity } \\
\text {-Stress dissipation }\end{array}$ & $\begin{array}{l}\text { - Static and dynamic elastic modulus } \\
\text { - Stress under the sub-ballast }\end{array}$ \\
\hline Permeameter & UNE-EN 103403:1999 & 25 & Permeability & -Evolution of permeability \\
\hline
\end{tabular}

set at a speed of $350 \mathrm{rpm}$ for a period of 10 minutes, in accord with (22).

\subsection{Methods}

In order to compare the mechanical performance of the WMA with that presented by conventional HMA, a number of laboratory tests were carried out to characterize their behaviour and to evaluate their response under different failure modes that can take place during the real service life of these materials in railway tracks.

Table 2 summarizes the tests performed, the properties tested, and the main parameters investigated in this study.

Furthermore, the influence of temperature was evaluated, since the bituminous mixtures have high temperature susceptibility, becoming more viscous as their temperature decreases, and showing more rigid behaviour, all of which implies greater susceptibility to premature cracking induced by fatigue. Conversely, the materials become less viscous as their temperature increases, behaving more flexibly and showing higher permanent deformations under loading $(23,24)$. This evaluation was conducted to determine the possibility of using the sub-ballast under a range of different temperatures (both standard and adverse) that are expected in railway tracks.

Marshall test (EN 12697-34:06), water sensitivity test (UNE-EN 12697-12:2009) and indirect tensile stiffness modulus test (UNE-EN 1269726:2012, Annex C) were developed to characterize both types of bituminous sub-ballast. The cyclic triaxial test (EN 12697-25, Method B), and the punching test were conducted to evaluate the resistance to plastic deformations of both types of sub-ballast. The tests were run both at temperature of service for this layer in railway tracks, and at higher temperatures, where plastic deformations are more likely to develop in asphalt mixtures. The plate bearing test (UNE-EN 103807:2008), was developed to measure the bearing capacity of the layer as well as its capacity to dissipate the stresses 
transmitted to the sub-grade, at both standard and high temperatures $\left(25\right.$ and $\left.40^{\circ} \mathrm{C}\right)$ that can modify the endurance of mix asphalt. Finally, the permeameter test (UNE-EN 103403:1999) was conducted to assess its capacity to waterproof the remainder of the substructure, since permeability is scarcely affected by temperature.

The Marshall test was conducted to determine the percentage of voids in the mixes, along with the bulk density, deformation, and stability for the mixtures. The test was carried out on 3 cylindrical specimens (of approximately $60 \mathrm{~mm}$ in height and $101.6 \mathrm{~mm}$ in diameter, compacted with 75 blows on each side by a Marshall hammer) that were immersed in water at a temperature of $60^{\circ} \mathrm{C}$ for $50 \pm 5 \mathrm{~min}$.

For the water sensitivity test, six cylindrical specimens of the Marshall type were manufactured, divided into two groups of three. This protocol involves conducting the indirect tensile strength test on a first set of specimens, treated with $67-72 \mathrm{~h}$ of immersion in a thermostatic bath at $40^{\circ} \mathrm{C}$, and on a second set left at room temperature for the same length of time, at a test temperature of $15^{\circ} \mathrm{C}$. The results are expressed in terms of the retained strength of the test cylinders after dividing the mean strength of the wet cylinders by the mean strength of the dry cylinders (ITSR, \%).

To determine the stiffness modulus of the mixes, the indirect tensile stiffness modulus test (ITSM) was conducted in accord with UNE-EN 12697-26, Annex C. The test temperature was $25^{\circ} \mathrm{C}$ for two cylindrical specimens (for the two types of mixtures) compacted with 75 blows on each side by a Marshall hammer. During the test, 15 semi-sinusoidal test pulses were applied along the vertical diameter of the specimens with a total duration of $3 \pm 1 \mathrm{~s}$, consisting of a rise time of $124 \pm 4 \mathrm{~ms}$ in a regime of deformation control $(5 \mu \mathrm{m})$. The test procedure was repeated in a perpendicular diameter. The stiffness modulus of the mixtures was recorded by taking the average stiffness of the five pulses registered in the two diameters.
The first test for evaluating the resistance of the mixes to plastic deformations was the cyclic triaxial test (Figure 2a) (UNE-EN 12697-25:2006, Method B). This test requires two cylindrical test specimens manufactured by an impact compactor (75 blows per side) (UNE-EN 12697-30:2013) with a height of approximately $60 \mathrm{~mm}$ and a diameter of $101.6 \mathrm{~mm}$. The specimens were tested at the standard expected temperature for sub-ballast in railway tracks $\left(25^{\circ} \mathrm{C}\right)$ and extreme temperatures of $40^{\circ} \mathrm{C}$ and $60^{\circ} \mathrm{C}$, which could occur in warm climates, and where plastic deformations are more likely to develop in asphalt mixtures. A conditioning period of $2 \mathrm{~h}$ was implemented before beginning the test. The experiment involved the application of a confinement load of $80 \mathrm{kPa}$ and another cyclic sinusoidal out-of-phase axial loading of $200 \mathrm{kPa}$ at a frequency of $3 \mathrm{~Hz}$ for 10,000 load cycles (25). At the end of the test, measures were recorded (average of two specimens) for creep modulus, creep slope at the final 5,000 loading cycles, and permanent deformation.

In addition, resistance to permanent deformations was evaluated by a punching test (Figure 2b), which is able to simulate the contact between the ballast and the asphalt layer (Figure 2c). The test was conducted at $25^{\circ} \mathrm{C}$ and $40^{\circ} \mathrm{C}$ and required a pair of test specimens of $300 \mathrm{~mm} \times 300 \mathrm{~mm}$ x $120 \mathrm{~mm}$, for each temperature and for both types of mix (HMA and WMA). The test consisted of applying a stress of $200 \mathrm{kPa}$ for 50,000 load cycles (regarded as an unfavourable loading condition that can occur over the sub-ballast layer) (10) by means of a ballast plate with dimensions of $150 \mathrm{~mm} \times 150 \mathrm{~mm}$ (Figure 2d) on the top of the sub-ballast specimen. The calculated parameter represents the evolution of the permanent deformation caused by the punching of ballast particles.

To evaluate the bearing capacity of the mixtures, as well as their capacity to dissipate the stress transmitted to sub-grade, a plate bearing test (Figure 3) (UNE-EN 103807:2008) was carried out. This test involved the manufacture of a prismatic test slab
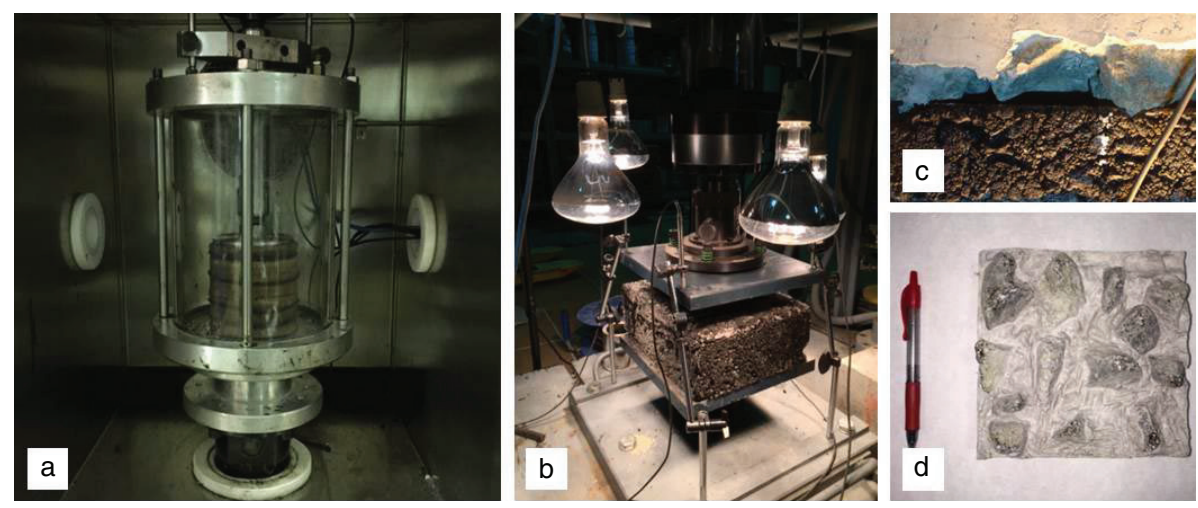

FIGURE 2. Configuration of the triaxial and punching tests. 


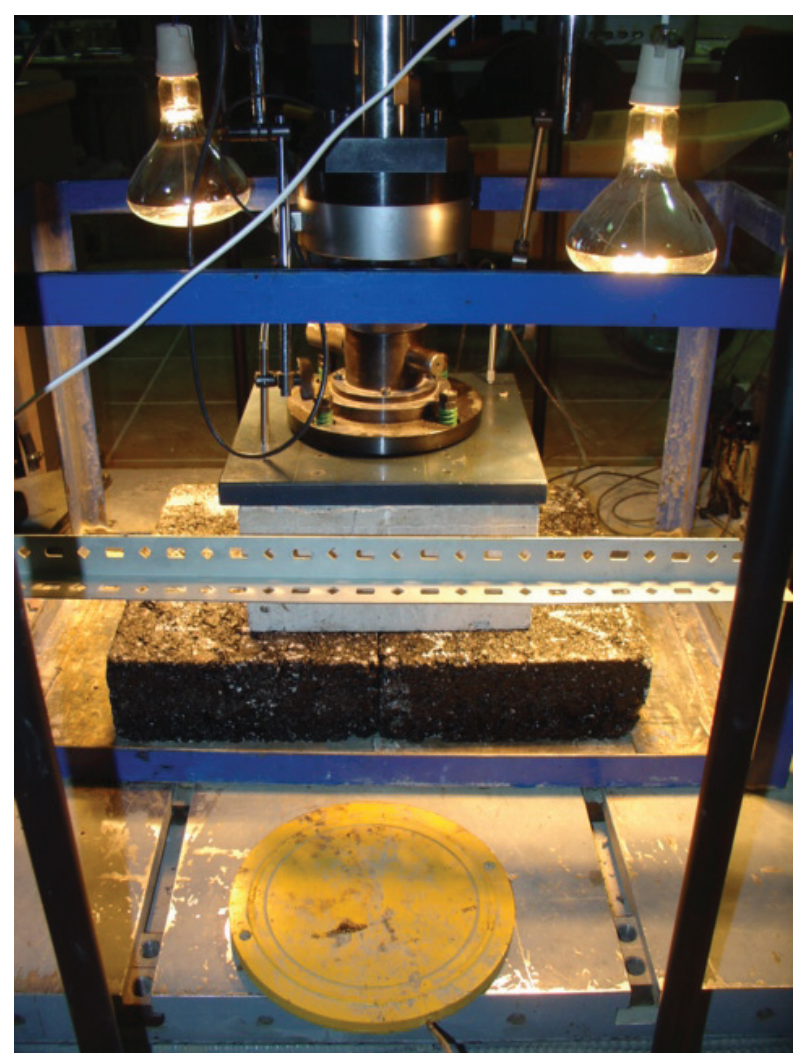

FIGURE 3. Plate bearing test and pressure cell.

of $408 \mathrm{~mm}$ x $512 \mathrm{~mm}$ for both types of mixture. A roller compactor with a smooth steel roller of $120 \mathrm{~mm}$ in thickness was employed for compaction. This test was conducted at $25^{\circ} \mathrm{C}$ and $40^{\circ} \mathrm{C}$, expected and high temperatures to modify the endurance of bituminous sub-ballast (26), under static and dynamic loads. For the static test, the load was applied at various stress levels: 20, 50, 150 and $250 \mathrm{kPa}$, across two charge cycles, while the dynamic test was carried out by applying a cyclic sinusoidal load of $200 \mathrm{kPa}$ at a frequency of $4 \mathrm{~Hz}$ for 50000 load cycles. Moreover, to analyse the capacity to distribute loads, a pressure cell was collocated at the bottom of each mixture.

To evaluate the permeability of the two types of sub ballast (WMA-HMA), a permeameter (Figure 4) of square section (a surface of $300 \mathrm{~mm} x$ $300 \mathrm{~mm}$, and $500 \mathrm{~mm}$ in height with a hole in the bottom to collect the water drained by the subballast through a pipe of the same diameter) was used. The constant-head method was applied in accordance with the Standard UNE-EN 103403:1999 that is usually used to determine the permeability of soils by Darcy's law. The parameter calculated the evolution of permeability in each type of sub-ballast, in accord with the methodology applied by other authors $(7,27)$ for the study of permeability of bituminous layers in railways.

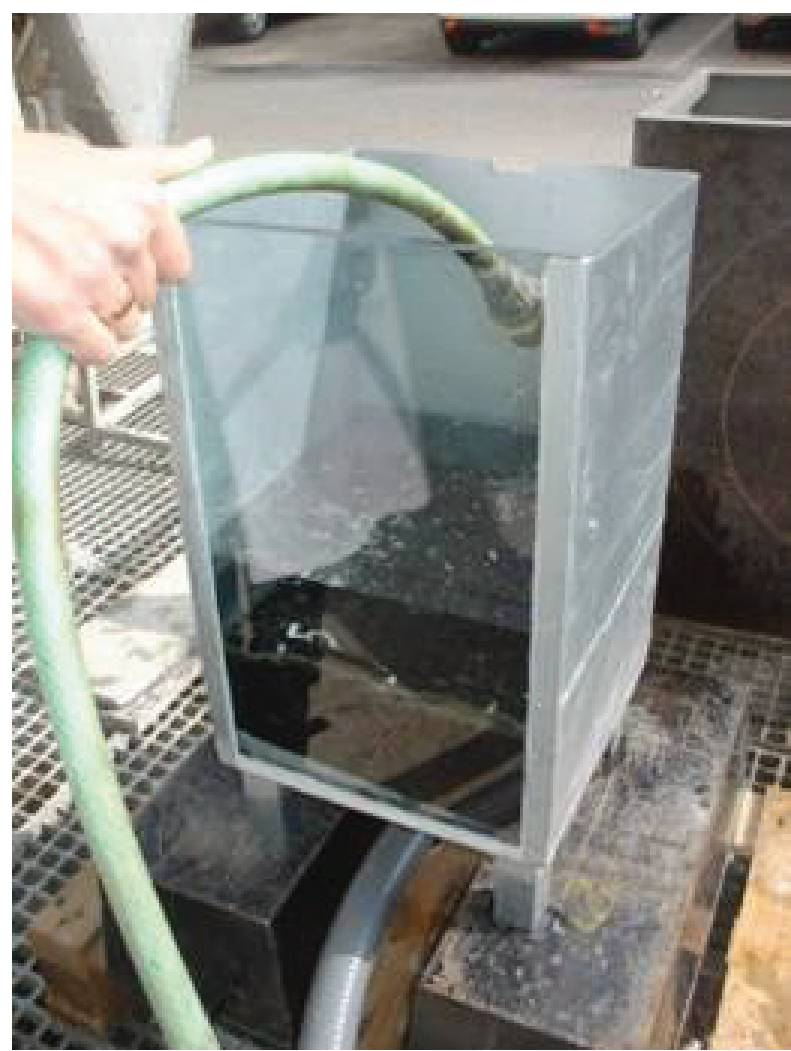

FiguRE 4. Permeameter.

\section{RESULTS AND DISCUSSION}

\subsection{Results of characterization}

The Marshall Test results indicate that the conventional hot mix asphalt and the warm mix have very similar values of density and air voids. This implies that use of the additive could improve the workability of the WMA, despite a $25^{\circ} \mathrm{C}$ reduction in the manufacturing temperature (13-16). It is also clear that in spite of the values of Marshall Flow being very similar for both mixtures $(3.4 \mathrm{~mm})$, there was a decrease of Marshall Stability in the warm mix sub-ballast.

The same occurred during the Water sensitivity test, where indirect tensile strength of WMA decreased with respect to that recorded for the conventional HMA. However, there was an improvement in the indirect tensile strength ratio (ITSR \%). This is probably due to the lower compaction temperature that could increase the potential for moisture damage as established in the studies carried out by Hurley $(14,28)$, since lower mixing and compaction temperatures can result in incomplete drying of the aggregate.

Stiffness (stress/strain ratio) generally decreases as the manufacturing temperature decreases $(29,30)$. The present results revealed a slight decrease of the modulus in the warm mix sub-ballast due to the decrease in manufacturing temperature that reduces 
TABLE 3. Setting of the tests

\begin{tabular}{|c|c|c|c|c|c|}
\hline Test & Indirect tensile tests & Triaxial cyclic test & Punching test & Plate bearing test & Permeameter \\
\hline \multirow[t]{6}{*}{ Setting } & \multirow{2}{*}{$\begin{array}{l}-15 \text { semi-sinusoidal test } \\
\text { pulses }\end{array}$} & -lateral pressure $80 \mathrm{kPa}$ & \multirow{2}{*}{$\begin{array}{l}\text {-maximum pressure } \\
200 \mathrm{kPa}\end{array}$} & \multirow{2}{*}{$\begin{array}{l}\text { static test: load: } 20,50 \\
150,250 \mathrm{kPa}\end{array}$} & \multirow{6}{*}{$\begin{array}{l}\text {-constant-head } \\
\text { method }\end{array}$} \\
\hline & & -axial pressure $200 \mathrm{kPa}$ & & & \\
\hline & -total duration of pulse & -10000 cycles & -50000 cycles & \multirow{4}{*}{$\begin{array}{l}\text { - dynamic test: } \\
\text {-maximum pressure } 200 \\
\mathrm{kPa} \\
-1000 \text { cycles } \\
-4 \mathrm{~Hz}\end{array}$} & \\
\hline & & $-4 \mathrm{~Hz}$ & $-4 \mathrm{~Hz}$ & & \\
\hline & -rise time $124 \pm 4 \mathrm{~ms}$ & & & & \\
\hline & -deformation control $5 \mu \mathrm{m}$ & & & & \\
\hline
\end{tabular}

TABLE 4. Main properties of the asphalt mixture used as sub-ballast

\begin{tabular}{llcc}
\hline Properties & Standard & HMA & WMA \\
\hline Marshall test & & & 4.25 \\
Bitumen Content (\% over the total weight of the mixture) & - & 2.643 & 2.646 \\
Maximum Density (Mg/m3) & EN 12697-5:10 & 2.573 & 2.575 \\
Bulk Density (Mg/m3) & EN 12697-6:12 & 2.7 \\
Air Voids (\%) & EN 12697-8:03 & 2.6 & 9.967 \\
Marshall Stability (kN) & EN 12697-34:06 & 13.306 & 3.4 \\
Marshall Flow (mm) & EN 12697-34:06 & 3.4 & 1600.3 \\
Water sensitivity test & & 2159.9 & 1490.2 \\
Indirect tensile strength for the dry set (kPa) & EN 12697-12:09 & 1857.8 & 93.1 \\
Indirect tensile strength for the wet set (kPa) & EN 12697-12:09 & 86.0 & \\
Index of retained tensile strength after water action (\%) & EN 12697-12:09 & & \\
ITSM & & 5338 & 4669 \\
Stiffness Modulus at $25^{\circ} \mathrm{C}(\mathrm{MPa})$ & EN 12697-26:12 & \\
\hline
\end{tabular}

the aging of the mixtures, along with its stiffening, which is in accord with other studies (29). Table 4 lists the main properties of these materials.

\subsection{Resistance to plastic deformations}

The results of the triaxial test (Figure 5) show that the values of permanent deformation, slope of deformation, and creep modulus recorded for the warm mix sub-ballast are very similar to those presented by hot mix sub-ballast at both 25 and $40^{\circ} \mathrm{C}$. This fact indicates the possibility that warm mix could be used as a sub-ballast without increasing plastic deformations, since it has been shown that under the standard temperatures of service expected for sub-ballast in railway tracks (around $25^{\circ} \mathrm{C}$ ), conventional sub-ballast shows higher resistance to plastic deformations than that of the conventional granular sub-ballast $(7,25)$. However, increasing the temperature to $60^{\circ} \mathrm{C}$ (as expected in extreme climatic conditions) led to a decrease in resistance to permanent deformation for the WMA, with values of final deformation and creep modulus being lower than those obtained for the HMA. This implies that WMA could be more vulnerable to deformations than the granular layer (7). However, it should be noted that it is rare to achieve such extreme temperatures in real-life service, since the ballast layer usually protects the subballast from high temperatures.

The punching test was carried out to evaluate the resistance to plastic deformations under more realistic load conditions. Starting from the deformation curves obtained during the test at 25 and $40^{\circ} \mathrm{C}$ for both bituminous sub-ballast (HMA and WMA), it was possible to determine the initial and final deformation and the slope of the creep curve of the stable phase (7). The initial deformation (primarily associated with the recompaction and reorganization of particles) was determined at around 700 cycles, the point at which the deformation response tends to stabilize. This point until the end of the test $(50000$ cycles), may be regarded as the stable phase to determine the slope of the curve. In addition, the final deformation was determined at 50000 cycles.

The results (Figure 6) show that the warm mix subballast presented values of initial and final permanent deformation equal to or very similar to those obtained for the hot mix sub-ballast at both temperatures. The slope of the creep curve increased slightly in the case of WMA, however in the order of very similar values compared to those recorded for the HMA. Thus, under routine in-service temperatures $\left(25^{\circ} \mathrm{C}\right)$ and at higher temperatures (particularly $40^{\circ} \mathrm{C}$ ), the effects 


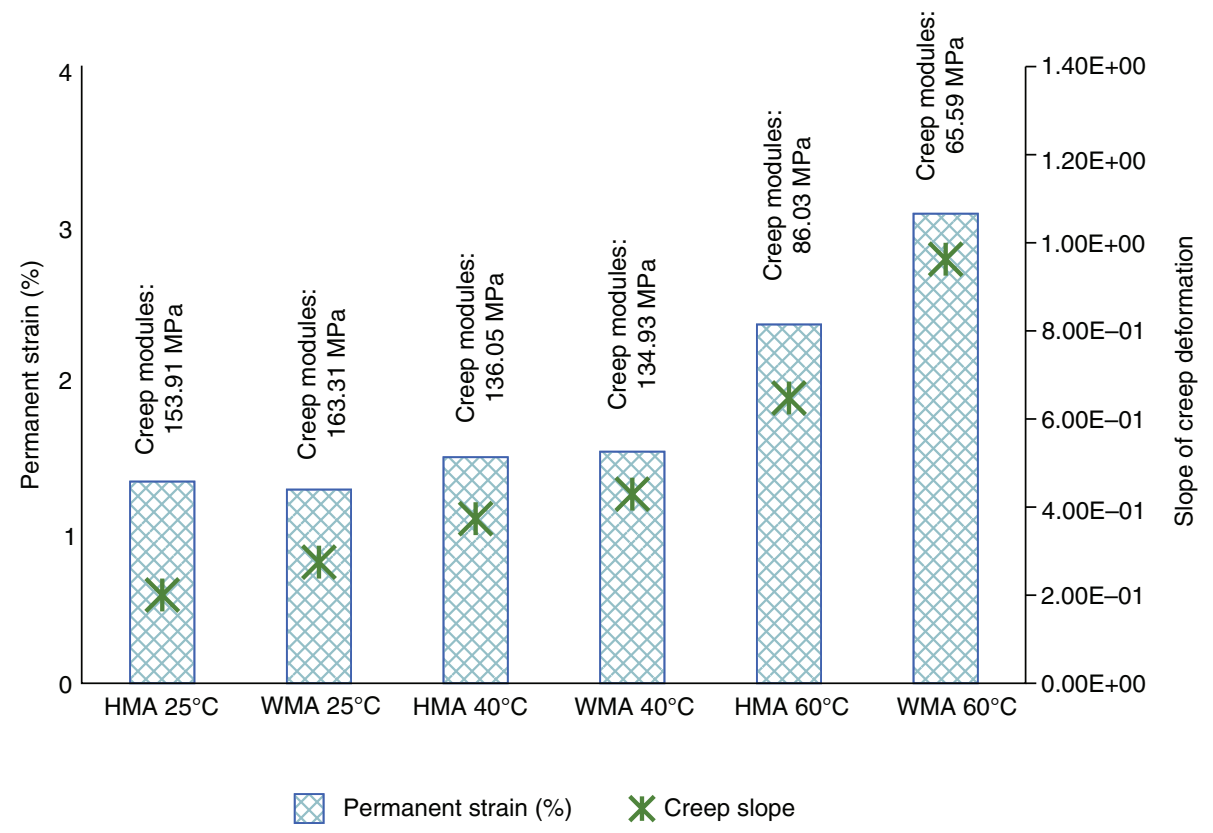

Figure 5. Results measured from the triaxial test: Resistance to plastic deformations.

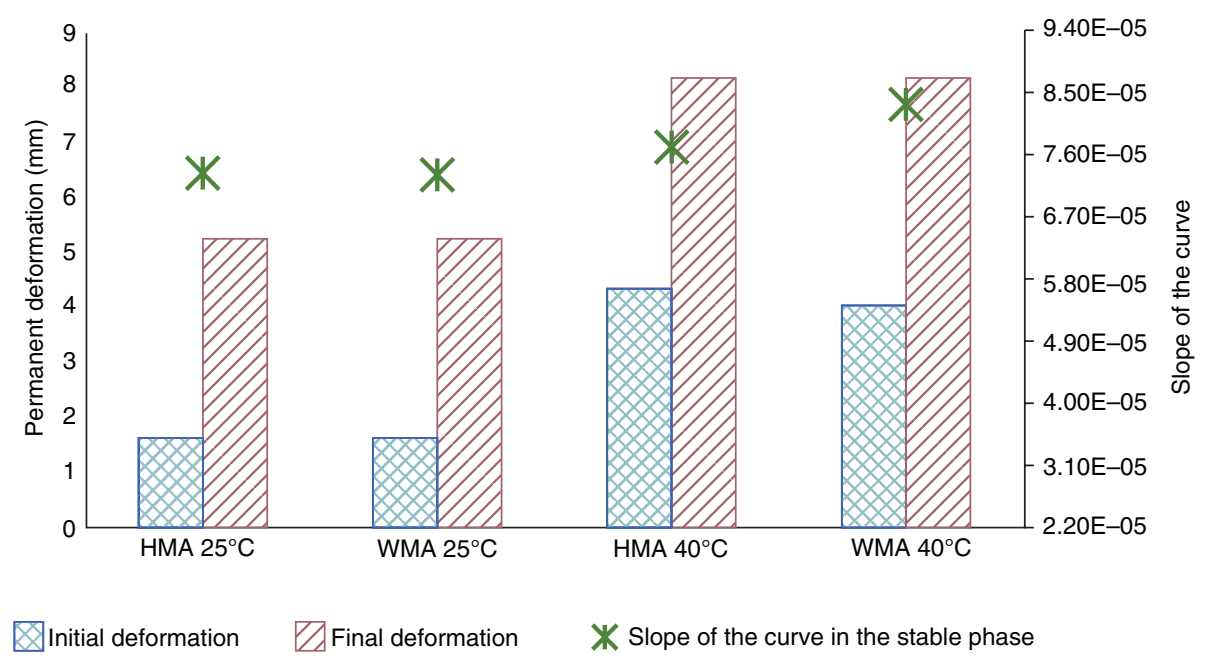

FIGURE 6. Results of the punching test for both sub-ballasts at different temperatures.

due to ballast punching were very similar for both mixtures in both the short and long-term. Further, and in accord with other studies, the results obtained are lower in comparison with the traditional granular subballast (7). This indicates the possibility of using warm mix asphalt as sub-ballast in railway tracks without increasing the appearance of plastic deformations.

\subsection{Bearing capacity and dissipation of stress}

Regarding the bearing capacity of both subballast types, Figure 7 displays the static and dynanmic modulus obtained during the Plate bearing test at $200 \mathrm{KPa}$, which was designed to reproduce unfavorable loading conditions expected in railway tracks for this layer. It is clear that both bituminous sub-ballast recorded similar values of resistance to loads transmitted by trains, even at the higher temperature $\left(40^{\circ} \mathrm{C}\right)$ in both static and dynamic conditions. According to earlier studies, the application of hot mix asphalt as sub-ballast was able to improve the bearing of the layer compared to that obtained by the more traditional granular configuration $(7,25)$. For this reason, the present results indicate that WMA could be appropriate for application in 


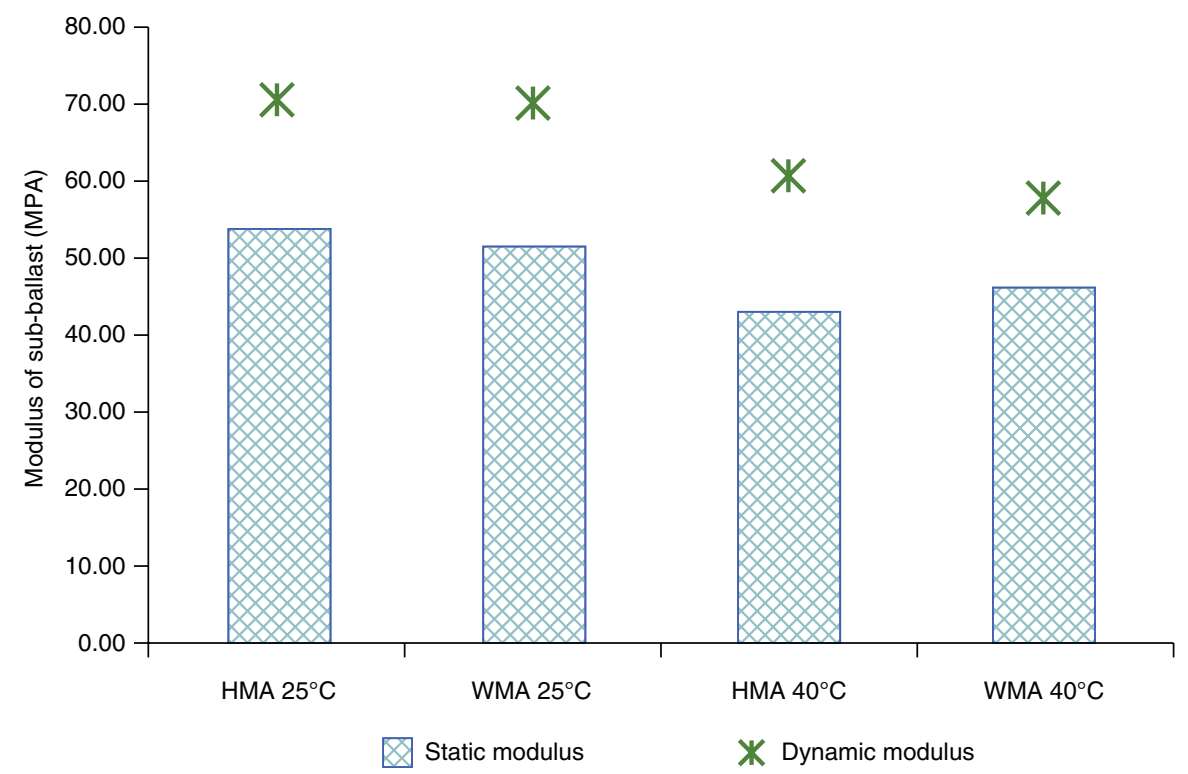

FIGURE 7. Static and dynamic modulus for both types of sub-ballast.

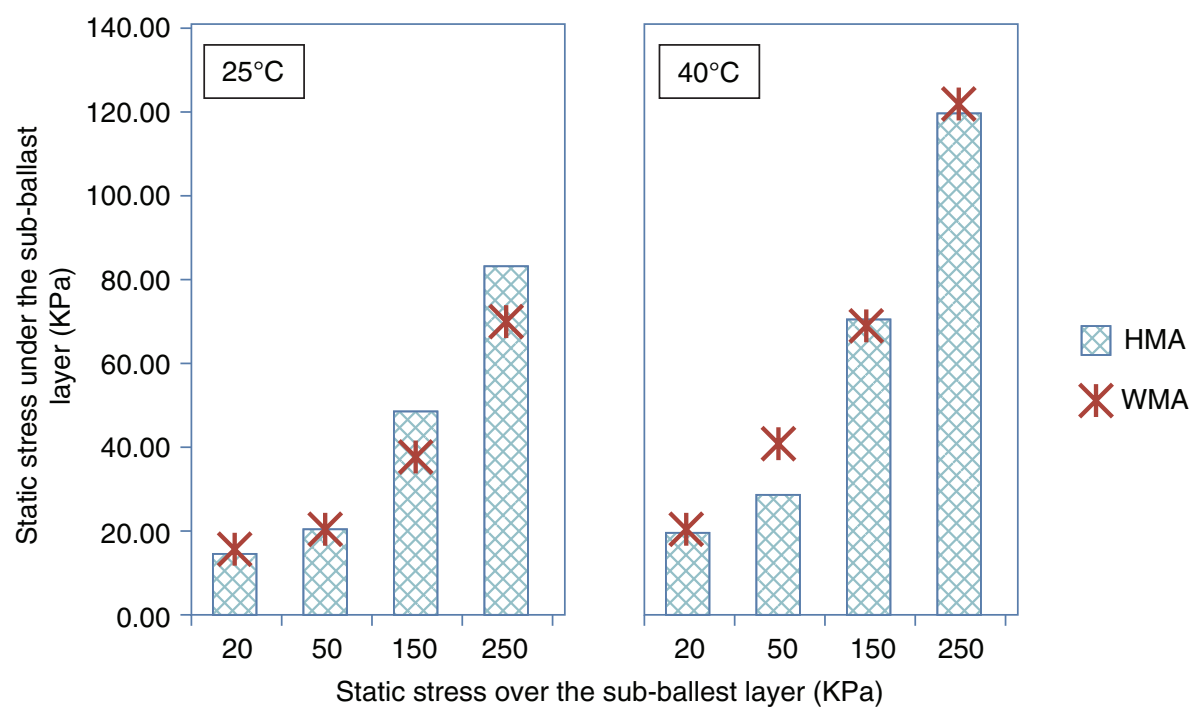

FIGURE 8. Results of static stress under sub-ballast layer during the plate-bearing test.

railway tracks, since it has presented a similar performance to that measured for conventional bituminous sub-ballast.

The results regarding bearing capacity were in line with values of pressure recorded under the sub-ballast layer, by using pressure cells under static conditions (Figure 8) and dynamic conditions (Figure 9), for temperatures of 25 and $40^{\circ} \mathrm{C}$. It is clear that the pressure reaching down through the sub-ballast layer is quite similar for the two mixtures (HMA and WMA). This means that the decrease in the manufacturing temperature of the mixture has little effect on its capacity to dissipate the loads transmitted by the passage of trains. It can also be observed that an increase of the test temperature generally decreases the capacity of the mixtures to dissipate the stress. Despite this decrease, the values recorded for the warm mix sub-ballast are very similar to those recorded for the conventional bituminous sub-ballast. Furthermore, it is worth noting that the values of pressure registered are significantly lower (by up to $50 \%$ ) than those measured under the layer of the granular sub-ballast $(7,25,31)$. This implies that, in comparison with granular sub-ballast, bituminous sub-ballast is able to provide a more durable system, reducing maintenance and rehabilitation costs regardless of the temperature of manufacture. 


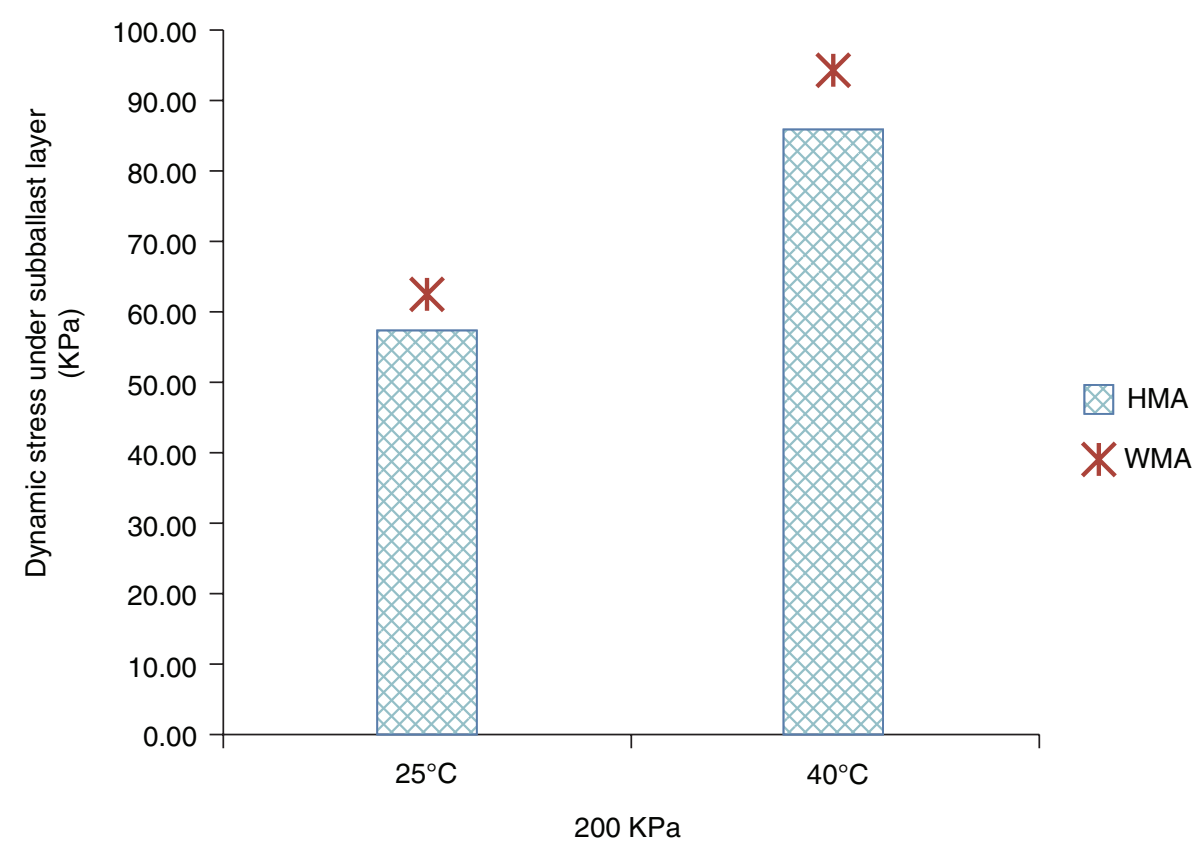

FiguRE 9. Results of dynamic stress under sub-ballast layer during the plate-bearing test.

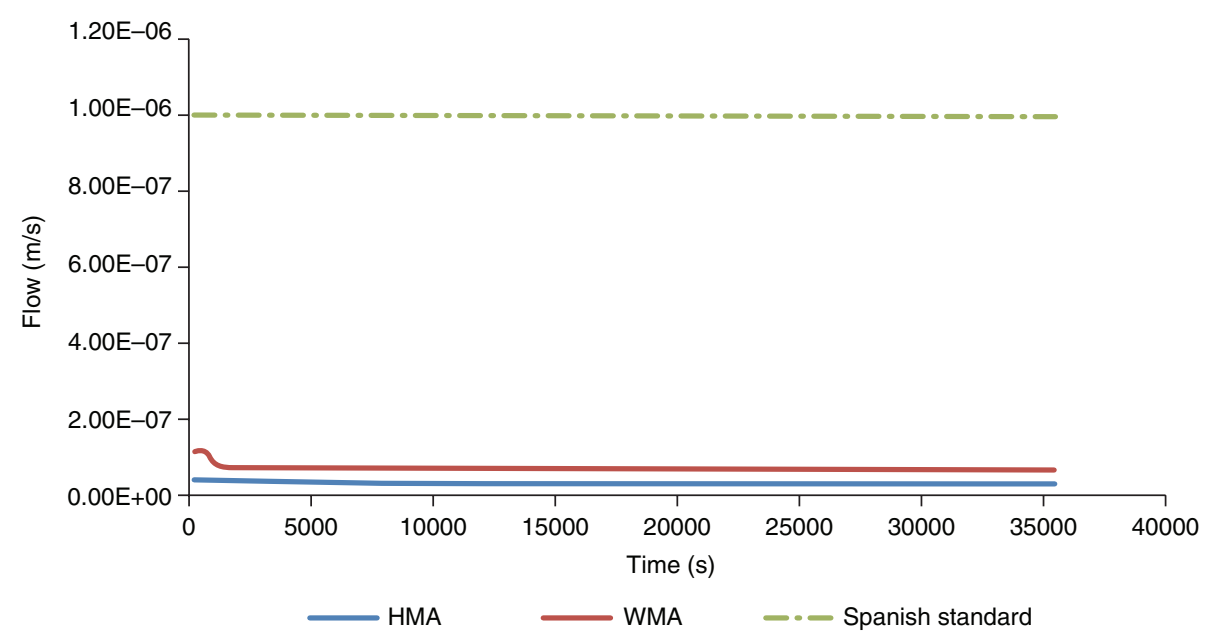

Figure 10. Evolution of the water flow drained by each type of sub-ballast: Permeability results.

\subsection{Permeability}

As mentioned previously, in addition to bearing capacity, another fundamental parameter for this layer is its capacity to waterproof the remainder of the substructure. This parameter is specified by the Spanish standard, which indicates that the vertical permeability coefficient of the sub-ballast $(\mathrm{K})$ must be less than $10-6 \mathrm{~m} / \mathrm{s}$ (32). Figure 10 shows the evolution of the drained flow for both types of sub-ballast used in this study (with a thickness of $12 \mathrm{~cm}$ ), analyzed using a constant-head permeameter. The HMA presents slightly lower values of flow compared to the those obtained by WMA. However, both mixtures have presented an appropriate coefficient of permeability for application in railway tracks according to the Spanish Standard for sub-ballast. The present results suggest that both types of sub-ballast have the capacity to prevent the possible contamination of the sub-structure by the vertical hydraulic transport of mud and fines, offering an impermeable uniform drainage layer that reduces the effects of freeze/thaw action and leads to a lower variation in the moisture content with respect to the granular configuration $(7,9,33)$.

\section{CONCLUSIONS}

The aim of this paper was to examine the mechanical behaviour of WMA as sub-ballast in railways tracks, under the main failure modes that 
take place during the service life of sub-ballast. To this end, several laboratory tests were carried out to analyse its response to the main functions that the sub-ballast layer must perform for its application in railway tracks. Thus, a comparative analysis was developed between the alternative WMA subballast and the conventional HMA sub-ballast. On the basis of the results obtained the following main conclusions can be drawn:

- The characterization tests revealed that both mixtures present very similar values of density and air voids in spite of lowering the temperature. Moreover, the use of the chemical additive to decrease the manufacturing temperature served to reduce the susceptibility to water action. However, for the warm mix asphalt, a slight decrease in strength and stiffness modulus was observed, obtaining a material that was less rigid and more flexible.

- Under routine in-service temperatures expected for sub-ballast in railway tracks (around $25^{\circ} \mathrm{C}$ ) and at higher temperatures (particularly $40^{\circ} \mathrm{C}$ ), the mixtures presented very similar levels of resistance to plastic and punching deformations, which indicates the potential for using warm mix asphalt as sub-ballast in railway tracks without increasing the appearance of plastic deformations. However, increasing the temperature to $60^{\circ} \mathrm{C}$ (extreme temperatures) led to a decrease in resistance to permanent deformations in both mixtures, but more notably in the WMA which showed greater vulnerability to deformations than the granular configuration.

- Although bituminous sub-ballast resistance and its ability to dissipate stress decreases with temperature, both bituminous sub-ballasts registered similar values of resistance to the loads transmitted by trains, even at a higher temperature $\left(40^{\circ} \mathrm{C}\right)$ in both static and dynamic conditions. This means that the WMA presented a similar bearing capacity to that measured for conventional bituminous sub-ballast, obtaining higher vertical strength than that of the granular layer. Moreover, similar values of stress at the bottom of the layer were recorded, which means that both types of bituminous sub-ballast have a similar capacity to dissipate stress.

- Applying the bituminous sub-ballast (regardless of the manufacturing temperature) can improve waterproofing and filter properties, preventing the contamination of both the sub-structure and the ballast layer whilst also offering a satisfactory coefficient of permeability $(\mathrm{K})$ value.

Based on the results presented in this study, WMA sub-ballast presented a comparable performance to that measured for conventional bituminous sub-ballast. In addition, its application would allow for important economic and environmental benefits in reference to the conventional bituminous subballast manufactured from HMA. Nonetheless, further studies are needed to assess the performance of WMA under a range of failure modes expected for asphalt materials, including, for instance, resistance to cracking, which is a fundamental parameter in asphalt materials since it is of crucial importance in protecting the substructure.

\section{REFERENCES}

1. Selig, E.T.; Waters, J.M. (1994) Track technology and substructure management Thomas Telford, London.

2. Teixeira, P.F.; López-Pita, A.; Casas-Esplugas, C.; Bachiller, A.; and Robusté, F. (2006) Improvements in highspeed ballasted track design: Benefits of bituminous subballast layers. Transp. Res. Rec., 1943, 43-49. https://doi. org/10.3141/1943-06.

3. Teixeira, P.F.; Ferreira, P.A.; López Pita, A.; Casas, C.; Bachiller, A. (2009) The use of bituminous sub-ballast on future high-speed lines in Spain: Structural design and economical impact. IJR International Journal of Railway, 2, 1-7.

4. Rose, J.G.; Teixeira, P.F.; Veit, P. (2011) International Design Practices, Applications, and Performances of Asphalt /Bituminous Railway Trackbeds". GEORAIL, Paris, France.

5. Asphalt Institute (1998) HMA Trackbeds-Hot Mix Asphalt for Quality Railroad and Transit Trackbeds, Informational Series $137,10 \mathrm{p}$.

6. Fang, M.; Rose, J.G.; West, R.C.; Qiu, Y.; (2011) Ai C. Comparative analysis on dynamic behavior of two HMA railway substructures. J Transp Res Board; 19(1):26-34; http://dx.doi.org/10.3969/j.issn.2095-087X.2011.01.005.

7. Sol-Sánchez, M.; Pirozzolo, L.; Moreno-Navarro, F.; RubioGámez, M.C. (2015) Advanced characterisation of bituminous sub-ballast for its application in railway tracks: The influence of temperature. Construc. Build. Mat. 101 338-346; http://dx.doi.org/10.1016/j.conbuildmat.2015.10.102.

8. CENIT (2005) Estudio sobre la viabilidad de incorporar capas de sub-balasto con material bituminoso en las líneas de alta velocidad en España-Fase 2. 252 pp. Conf. Report.

9. Rose, J.G.; Bryson, L.S. (2009) Hot mix asphalt railway trackbeds: trackbed materials, performance evaluations, and significant implications. International Conference on Perpetual Pavements, Columbus, Ohio, USA.

10. Rose, J.G.; Teixeira, P.F. (2010) Ridgway NE. Utilization of asphalt/bituminous layers and coatings in railway trackbeds - a compendium of international applications. ASME Joint Rail Conf; 1:239-56.

11. Jiménez del Barco-Carrión, A.; García-Travé, G.; MorenoNavarro, F.; Martínez-Montes, G.; Rubio-Gámez, M.C. (2016) Comparison of the effect of recycled crumb rubber and polymer concentration on the performance of binders for asphalt mixtures. Mater. Construcc. 66 [323], e090. http://dx.doi.org/10.3989/mc.2016.08815.

12. López-López, E.; Vega-Zamanillo, A.; Calzada-Pérez, M.A.; Taborga-Sedano, M.A. (2015) Use of bottom ash from thermal power plant and lime as filler in bituminous mixtures. Mater. Construcc. 65 [318], e051 http://dx.doi. org/10.3989/mc.2015.01614.

13. Alonso, A.; Tejeda, E.; Moreno, F.; Rubio, M., \& Medel, E. (2013) A comparative study of natural zeolite and synthetic zeolite as an additive in warm asphalt mixes. Mater. Construcc, 63(310): 195-217 doi: 10.3989/mc.2013.05911.

14. Rubio-Gámez, M.C.; Martínez, G.; Baena, L.; Moreno, F. (2012) Warm mix asphalt: an overview. J. Clean. Produc. 24, 76-84. https://doi.org/10.1016/j.jclepro.2011.11.053.

15. You, Z.; Goh, S.W. (2008) Laboratory evaluation of warm mix asphalt: a preliminary study. International Journal of Pavement Research and Technology 1 (1), 34e40. 
16. Zaumanis, M. (2010) Warm mix asphalt investigation. Master of science thesis. Kgs.Lyngby: Technical University of Denmark in cooperation with the Danish Road Institute, Department of Civil Engineering.

17. Olard, F.; Noan, C. (2008) Low energy asphalts. Routes roads 336/337. PIARC (World Road Association). p. 131-45.

18. EAPA. (2010) The use of warm mix asphalt - EAPA position paper. Brussels: European Asphalt Pavement Association.

19. Al-Rawashdeh, A.S. (2008) Performance Assessment of Warm Mix Asphalt (WMA) Pavements. PhD Thesis, Rus College of Engineering and Technology, Ohio University, Athens, USA.

20. Chowdhury, A.; Button, J.W. (2008) A Review of Warm Mix Asphalt. Texas Transportation Institute e Technical Report 473700-00080-1 College Station, USA.

21. Rohith, N.: Ranjitha, J. (2013) A Study On Marshall Stability Properties Of Warm Mix Asphalt Using Zycotherm A Chemical Additive. International Journal of Engineering Research \& Technology (IJERT). ISSN: 2278-0181. Vol. 2 Issue 7, July - 2013

22. Pérez-Lepe, A.; Martínez-Boza, F.J.; Gallegos, C.; González, O.; Muñoz, M.E.; Santamaría A. (2003) Influence of the processing conditions on the rheological behaviour of polymer-modified bitumen. Fuel, 82, 13391348. https://doi.org/10.1016/S0016-2361(03)00065-6.

23. Hafeez, I.; Hussain, J.; Riaz, K.; Khitab, A.; Hussain, S.; Zaidi, B.; Farooqi, U.; Hayat, A.; Ahmed, I.; Asif, A. (2013) Influence of time and temperature on asphalt rheological properties. Life Sci. J., 10, 894 898. http://www.lifesciencesite. com/lsj/life1012s/146_22330life1012s_894_898.pdf.

24. Moreno-Navarro, F.; Sol-Sánchez, M.; Rubio-Gámez, M.C. (2015) The effect of polymer modified binders on the long-term performance of bituminous mixtures: the influence of temperature. Mat. Des. 78, pp. 5-11. https://doi. org/10.1016/j.matdes.2015.04.018.
25. Rose, J.G.; Li, D.; Walker, L.A. (2002) Tests and evaluations of in-service asphalt trackbeds. American Railway Engineering and Maintenance-of-Way Association, Annual Conference \& Exposition, Washington, D.C., USA.

26. Minhoto, M.J.C.; Pais, J.C.; Pereira, P.A.A. (2008) The temperature effect on the reflective cracking of asphalt overlays. Mat. Pav. Des. 9, 615-632. https://doi.org/10.1080/146 80629.2008.9690141.

27. Parson, R.; Rahman, A.; Han, J. (2012) Properties of fouled railroad ballast (Phase 1). Mid-America Transportation Center. Final Report 25-1121-0001-465.

28. Hurley, G.; Prowell, B. (2006) Evaluation of Potential Processes for Use in Warm Mix Asphalt. Alabama : National Center for Asphalt Technology, Auburn University. NCAT report Nr.06-02.

29. Sanchez-Alonso, E. Vega-Zamanillo, A.; Castro-Fresno, D.; Del Rio-Prat, M. (2011) Evaluation of compactability and mechanical properties of bituminous mixes with warm additives. Constr Build Mater; 25:2304-11. https://doi. org/10.1016/j.conbuildmat.2010.11.024

30. Bennert, T.; Maher, A.; Sauber, R. (2011) Influence of production temperature and aggregate moisture content on the performance of warm mix asphalt (WMA). In: Nineteenth annual meeting of the transportation research board, Washington, DC, USA.

31. Rose, J.G. (2014) Maintaining adequate trackbed structural support- An important railway infrastructure issue. Seminar at University of Illinois at Urbana-Champaign, USA.

32. Spanish Standard for Subballast, PF-7 (2006) Pliego de Prescripciones Técnicas Generales de Materiales Ferroviarios PF-7, Subbalasto. Servicio de publicaciones del Ministerio de Fomento, Madrid.

33. Policicchio, F. (2008) Lineamenti di Infrastrutture Ferroviarie. Firenze University Press. 